\title{
特集＼cjkstart運動失調とリハビリテーション医学
}

\section{）神経メカニズムから捉える失調症状 \\ Atactic Symptoms Based on the Cerebellar Function}

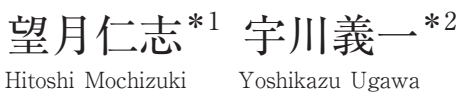

Key words：運動失調／小脳失調／感覚失調／前庭性失調／迷路性失調

運動失調とは, 運動麻痺はないもしくは軽症で, 動作や姿勢保持などの協調運動の障害であ る. 末梢感覚器（関節位置覚，視覚，平衡覚）から中枢神経系への求心路，その情報を処 理する小脳・大脳基底核，そして小脳などからの情報を受けて制御情報を送る大脳運動野か ら末梢・筋までの遠心路のどのレベルでも, 運動制御はされていることになる. これらのど の部分に障害が生じても, 臨床的な運動失調は生じる. 今回は, 臨床的に重要な小脳失調, 感覚失調，前庭性失調について，それぞれの臨床的特徵とその機序について概説した。

\section{はじめに}

運動失調とは, 運動麻痺（筋力低下）はないもし くは軽症で, 動作や姿勢保持などの協調運動に起 きる障害と定義できる，通常ヒトは，図１に示すよ うに末梢感覚器（関節位置覚, 視覚, 平衡覚) か ら, 脊髄・大脳皮質などの中枢神経系への求心路, その情報を処理する小脳・大脳基底核，そして小 脳などからの情報を受けて制御情報を送る大脳運 動野から末梢・筋までの遠心路のどのレベルでも， 運動制御を行っている。これらのどの部分に障害 が生じても，臨床的な運動失調は生じる.

\section{診断までの過程}

運動失調は, 責任病巣の違いにより, 小脳性運 動失調, 感覚性運動失調, 前庭性運動失調の 3 つ

\footnotetext{
$* 1$ 宮崎大学医学部内科学講座 神経呼吸内分泌代謝学分野

（ T889-1692 宮崎県宮崎市清武大字木原 5200）

E-mail : mochizuki-h@umin.net

*2 福島県立医科大学神経再生医療学

DOI : 10.2490/jjrmc.56.88
}

に大きく分けられる．丁寧な問診および神経診察 により, 責任病巣は多くの場合は特定可能である. 主な特徵・鑑別点を表 1 に示した.

診断までのステップは，すべての神経疾患の診 断に共通することではあるが, 初めに詳細な病歴 聴取を行う。その病因が突発発症型なのか, 急性・ 慢性進行型, 再発緩解型, 突発再発型なのかなど を聴取し，その疾患の病因を判断する。年単位で 緩徐進行性の場合には，遺伝性疾患を含めた神経 変性疾患を疑う。月単位で進行する場合は, 腫瘍 などの占拠性病変, 傍腫瘍症候群, 自己免疫性疾 患, 中毒疾患を疑う。日・週単位で進行する亜急 性の場合は, 感染症, 自己免疫疾患, 突発性の場 合は血管障害を疑う。突発再発型ではてんかん, 再発緩解型では自己免疫疾患, 代謝性疾患, 薬剂 性などを疑う。

次に, 神経診察による他覚的所見により病変部 位とその分布を判断し，障害部位を推定する，鑑 別点については後述するが, 運動失調の原因が小 脳性であるのか, 深部感覚性（脊髄性を含む）なの か，前庭性であるのか，どれにも当てはまらないの 


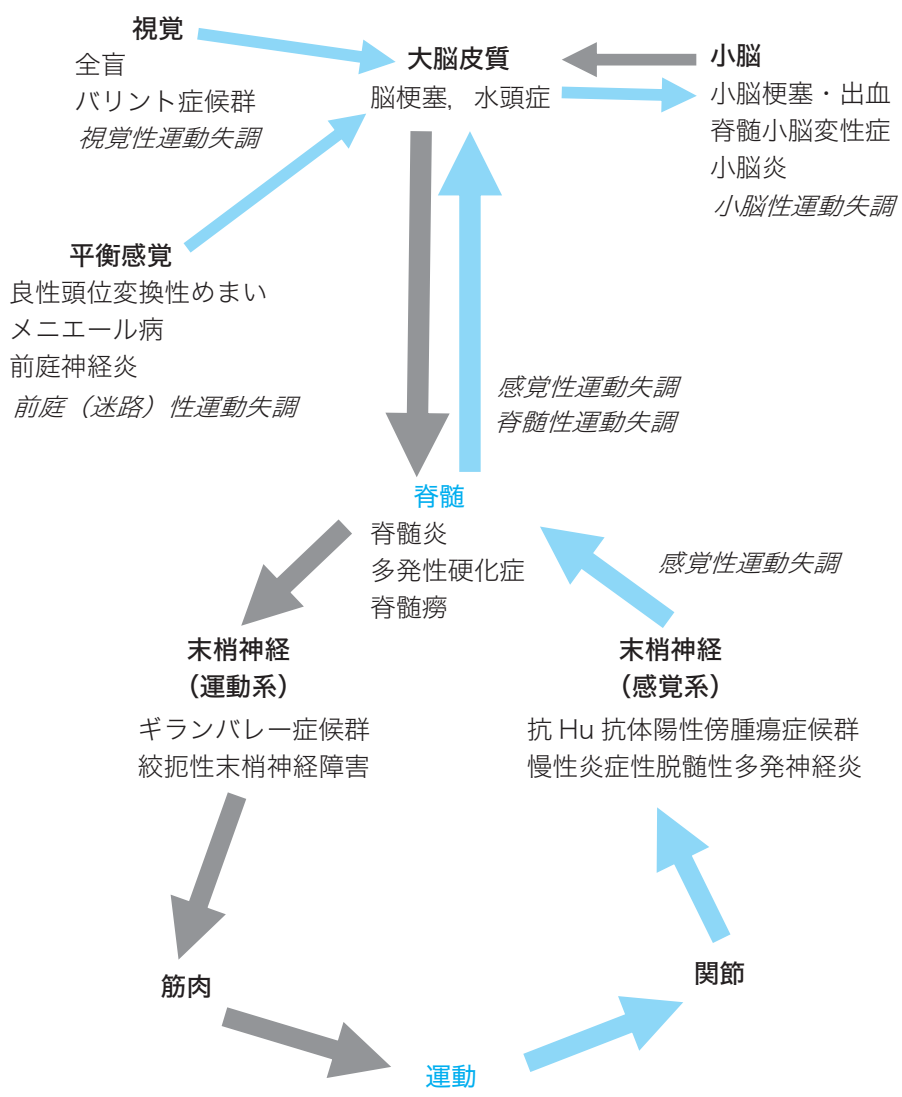

図 1 運動失調を生じる病変部位

それぞれの末梢感覚器（位置覚, 視覚, 平衡覚) から情報は上行し, 大脳・小脳で処 理して, 運動をつかさどる。この経路のいずれの障害によっても運動失調を生じる.

\section{表 1 運動失調の特徵}

\begin{tabular}{|c|c|c|c|}
\hline & 小脳性運動失調 & 感覚性運動失調 & 前庭性運動失調 \\
\hline 眼振 & + & - & + \\
\hline 言語障害 & 構音障害 & - & - \\
\hline 四肢の失調 & + & + & - \\
\hline 振戦 & 運動時の摇れ, 企図振戦 & 粗大な摇れ & - \\
\hline 深部感覚障害 & - & + & - \\
\hline Romberg 徵候 & - & + & - \\
\hline 歩行 & 酩酊様歩行 & 踵打歩行 & 一側へのふらつき歩行 \\
\hline 閉眼前後歩行 & 障害側にふらつく & & 星型歩行 \\
\hline \multirow[t]{6}{*}{ 主な疾患 } & 脊髄小脳変性症 & 脊髄癆, 泰髄炎 & 前庭神経炎 \\
\hline & 小脳梗塞, 小脳炎 & 春髄梗塞 & $x$ ニエール病 \\
\hline & フェニトイン中毒 & 亜急性連合性脊髄症 & 良性頭位変換性めまい \\
\hline & 急性アルコール中毒 & 多発神経根炎 & 聴神経腫瘍 \\
\hline & Ataxic hemiparesis & 春髄腫瘍 & 薬物中毒 \\
\hline & 傍腫瘍症候群 & Friedreich 病 & \\
\hline
\end{tabular}




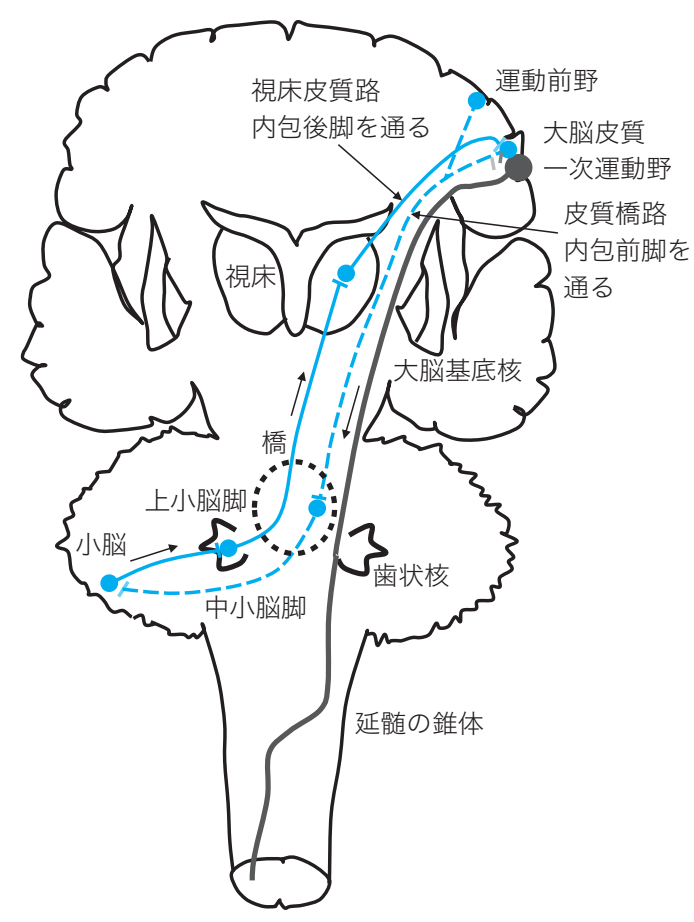

図 2 小脳と大脳皮質との回路図

小脳と大脳皮質との回路を示した。小脳遠心路は実線，小 脳求心路は点線で表した。 上記のどの部分が障害されても 小脳失調を呈する。

か, について検討する. 運動失調の分布, 左右差, 随伴する症状が，病巣部位の特定には有用である. そして, 鑑別診断を挙げ, 臨床診断を行っていく.

\section{小脳性運動失調}

小脳は, 大脳運動野と大脳基底核とともに大き く協調運動に寄与している. 小脳は, 発生学的お よび形態学的に, (1)小脳半球, (2)上部虫部, (3)下 部虫部，(4)片葉小節に分けられる．それぞれの部 位に関連する症状としては, 小脳半球は上肢・下 肢の協調運動で, 四肢の測定障害, 指鼻指試験で のゆらゆらという摇れ（ふるえではない, decomposition), 拙劣な反復拮抗運動, 筋トーヌスの低 下が挙げられる。 これらにより, 患側方向への偏 倚歩行, 協調運動障害, 運動の分解 (decomposition), 運動測定障害, 跳ね返り現象, 小脳性言語
（断続性，爆発性）を認める。上部虫部は正常歩行 と関連し，障害されると両足を広げて歩く widebased gait となり, 中等度以上の障害では両上肢 を広げてバランスをとるようにして歩行する。一直 線上のつぎ足歩行（tandem gait）が困難となる. 下部虫部は体幹運動の協調や平行機能と関連し, 立位をとるのみで身体ががくがくと前後上下に摇 れる。歩行は，酩酊様の歩容を示す，片葉小節は 前庭系を通じて眼球運動の協調に関与し, 一定方 向を向く前庭性眼振, 滑動性眼球運動の障害, 衝 動性眼球運動 (saccadic eye movement)を呈する.

小脳の運動機能調節に重要な経路は, 図 2 に示 すように, 小脳, 視床, 大脳皮質, 橋核が連絡を取 り合う回路である ${ }^{1)}$. 小脳の果たす役割は, 小脳に 入ってきたさまざまな段階の運動に関する情報と 大脳のどのような運動を行う予定かの情報に基づ き, 運動の結果を解析し, 大脳運動野・脊髄などに 制御の指令を出すことである. 小脳からのインパ ルスは, 大脳皮質へは上小脳脚を経て対側視床 $\rightarrow$ 対側大脳皮質運動野へと連絡する。大脳皮質運動 野からは, 橋を経て中小脳脚から小脳へと連絡す る.この経路のいずれが障害されても, 小脳性運 動失調を生じる.

純粋に小脳性運動失調の場合は, 筋力低下や深 部感覚に異常がなく, 起立時の不安定性はあるが Romberg 徵候は陰性で, 耳鳴り, 難聴の内耳障害 の症状はない. 陰性徴候を確認することにより, 他の原因による運動失調をある程度否定すること ができる.

小脳を障害する疾患すべてが小脳性運動失調の 原因となる. 突発発症型は小脳梗塞などの脳血管 障害, 進行性のものには小脳炎などの炎症, 抗 Yo 抗体関連の傍腫瘍症候群, 脳腫瘍, 脊髄小脳変性 症などの変性疾患, 再発緩解型には多発性硬化症, 肝性脳症, 薬剤性, アルコール性などの代謝性疾 患が挙げられる。 


\section{小脳磁気刺激法とその有用性}

Ataxic hemiparesis（AH）は臨床的には小脳失 調と錐体路徴候が認められ，上に述べてきたよう な小脳-大脳皮質経路のいずれかの部位の機能障 害によると考えられているが, 実際にその部位で症 候が起きていることを画像所見以外で示すことは 困難であった。 そのような中で, 磁気刺激法の発 達によりヒトの小脳機能を非侵襲的に評価するこ とが可能となった ${ }^{2,3)}$. この手法を以下に簡単に述 べる. 一次運動野を磁気刺激（試験刺激）すると, 対側の手筋に motor evoked potential (MEP) が 観察される.この試験刺激に $5 \sim 7 \mathrm{~ms}$ 先行して対 側小脳に磁気刺激 (条件刺激) すると, 条件刺激が ない場合の MEP と比較して, MEP が50\%近く抑 制される抑制効果がある. 小脳もしくは小脳遠心 路に障害があると, この抑制効果が減弱・消失す る. 例えば, 脊髄小脳変性症ではこの抑制効果は 減弱するが, Fisher 症候群のように小脳遠心路障 害とは関係のない場合（小脳求心路の障害）はこ の抑制効果は保たれる ${ }^{3,4)}$.

2012 年 Kikuchi $ら^{5)}$ は, 病変部位の異なる $\mathrm{AH}$ 患者 3 名につき, 小脳磁気刺激法を実施し, この 方法が $\mathrm{AH}$ の病態解明に有用であることを報告し た．例えば，小脳遠心路に位置する視床に病変が あった AH 患者 (図 3-a $)^{5}$ におおいては，患側は条 件一試験刺激間隔 $5 \sim 7 \mathrm{~ms}$ における平均の $\mathrm{MEP}$ 抑制比率（average area ratio：AAR）が 1.14 と, 通常認める抑制パターンが消失していた（正常は 0.78 以下に抑制される)。一方, 小脳遠心路に位置 しない中心溝の前後に病変が存在する $\mathrm{AH}$ 患者 (図 3-b $)^{5)}$ では, AARは 0.66 と正常の抑制パター ンを認めた．この論文の中で, 小脳遠心路と小脳 求心路のどちらにおいても $\mathrm{AH}$ が生じることを生 理学的に示している.

\section{感覚性運動失調}

小脳機能の障害以外による失調性歩行の原因と して, 脊髄後索や末梢神経障害による深部・固有 感覚の強い障害（大径線維の障害）による脊髄性 運動失調がある。体の平衡は, 末梢からの位置覚, 関節角度などの深部感覚が脊髄後根から脊髄後索 を経由して小脳, 前庭に上行するが, この経路が 障害されると歩行が不安定になる。この場合には, 視覚で平衡を保っているため, 閉眼して視覚入力 を遮断すると, 平衡を失って倒れそうになる (Romberg 徵候陽性または洗顔現象)。歩行は小 脳性運動失調とは異なり, 膝を必要以上に高く上 げ，前に放り出すようにして，パタンパタンと歩く (踵打歩行). 踵打歩行は, 障害された深部感覚を できる限り利用しようとする要素と, 深部感覚障害 のため足をどのくらい上げればよいのか, どの位置 で地面に到達するのか, 適切な判断ができない要 素とによって生じると考えられる. 上肢の深部感 覚障害が出現すると, 一定の筋力が保持できずに ものを落とすことがある．指を伸ばして閉眼する と指の位置が認知できずにアテトーゼ様の動きと なり，ピアノを弾いているような動きになる（piano playing finger).

春髄障害と末梢神経障害の区別には, 神経学的 診察所見にて感覚障害の分布, 腱反射充進と低下 の分布によって主病変部位の推測・特定が可能で ある. また, 脊髄瘞のように後根・後索が障害され る場合は体性感覚誘発電位 ${ }^{6}$, 未梢神経障害の場 合は神経伝導検査による神経生理学的検査が病変 部位特定に重要である. 神経伝導検査において感 覚神経活動電位の低下があれば，後根神経節より も遠位の末梢神経障害と推測できる.

脊髄後索の重度の障害をきたす疾患としては, 以前は梅毒による脊髄瘞が多かったが, 現在は少 ない，他には，ビタミン $\mathrm{B}_{12}$ 欠そによる亜急性連合 

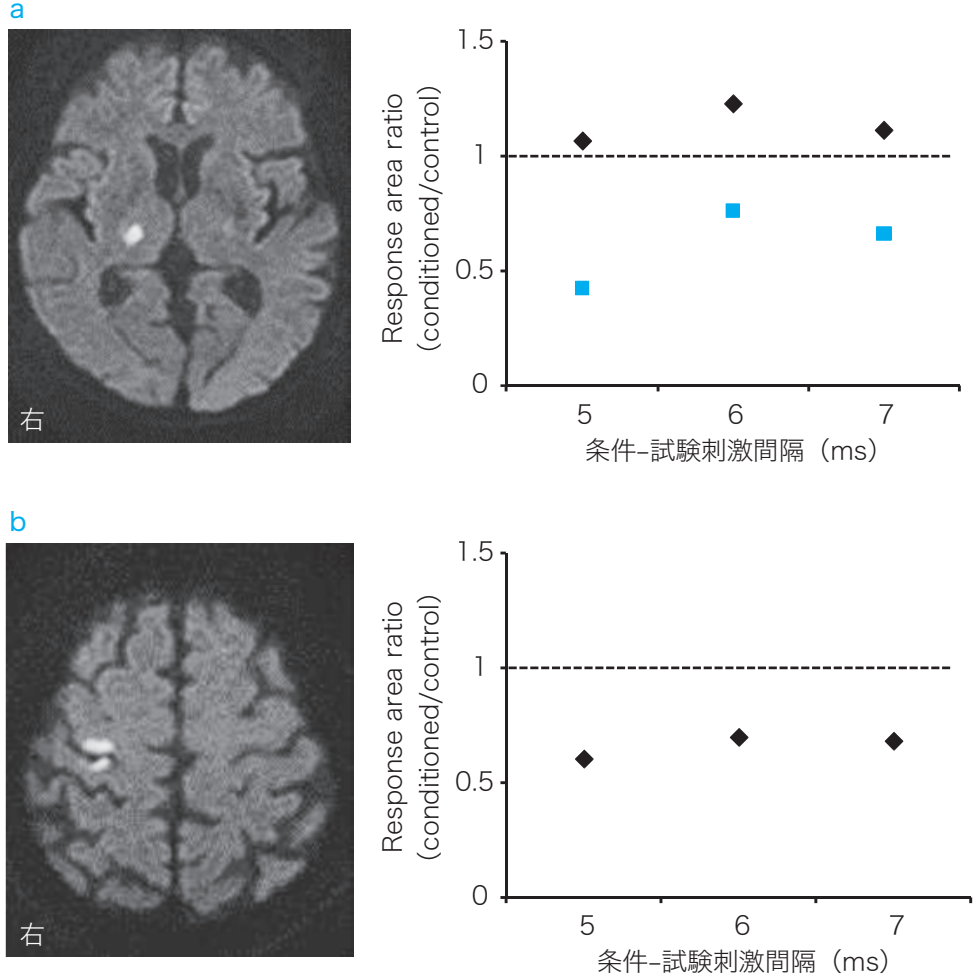

•失調のある側

AAR $=0.66$

(正常抑制あり)

- 失調のある側

$\mathrm{AAR}=1.14$

（正常抑制なし）

- 失調のない側

$\mathrm{AAR}=0.62$

(正常抑制あり)

図 3 Ataxic hemiparesis (AH) の 2 症例における小脳磁気刺激法による評価（文献 $5 よ$ り改変)

a : 症例 1 小脳遠心路に位置する右視床病変における $\mathrm{AH}$ 患者. 失調側では, 抑制パターンの欠如, 健康側では, 正常の抑制パターンを呈した.

$\mathrm{b}$ : 症例 2 小脳遠心路に位置しない右中心溝前後の病変における $\mathrm{AH}$ 患者. 失調側で，正常の抑制パターンを呈した。

AAR : average area ratio（条件-試験刺激間隔 $=5 \sim 7 \mathrm{~ms}$ )

性脊髄症，後脊髄動脈症候群による後索障害があ る．また，強度の深部感覚障害を呈する末梢神経 障害である抗 $\mathrm{Hu}$ 抗体陽性の傍腫瘍症候群，抗 myelin associated glycoprotein (MAG) 抗体関連 末梢神経障害などでも同様の運動失調を生じる.

\section{前庭性（迷路性）運動失調}

前庭器官の末梢受容体は三半規管で, ここから の求心系は前庭神経核を介して，小脳片葉，小節 に入力する。この経路のどの部分が障害されても 前庭性運動失調が生じる.

小脳失調との鑑別が容易でないときもあるが, 明らかな回転性めまいを訴える場合，あるいは「頭
の中がフラフラする」と訴える場合, 耳鳴りや難聴 を伴っている場合，姿勢性（頭位変換性）眼振，回 旋性眼振を伴っている場合には前庭性のことが多 い. 失調症状は偏倚（歩行時の片側へのふらつき 〔deviation〕がみられる。四肢の小脳失調はない， 50１00 歩の閉眼足踏みテスト（Fukuda test）で は，前庭障害では体が徐々に回転していくが，小 脳障害では体がいつも同じ側に倒れる。同様に Babinski-Weil テストも有用で，これは閉眼した患 者を数歩前進, 数歩後退させることを繰り返す検 査法である7)。前庭障害患者では前進するときは 患側に，後退するときは健側に片寄り星型歩行・羅 針盤歩行（compass gait）になる，小脳失調患者 
では前進時も後退時も常に障害側に片寄る.

多くは内耳性障害疾患に起因，もしくはその後 遺症として生じている. メニエール病, 前庭神経 炎, 突発性難聴, カナマイシンなどによる薬剤性前 庭神経障害，髄膜炎，音響外傷などがある。

\section{診断のための検査}

病変部位の特定のためには，上記に示したよう に神経学的診察がきわめて有用である．診察所見 以外に，血液，尿検査などの通常実施する検査に 加えて, 神経感染症 - 中枢神経系の炎症性疾患を 疑う場合は髄液検査を行う。画像診断は，突発性 発症の場合は脳出血などの否定のために CT が有 用であるが, 変性疾患, 代謝疾患の鑑別のために は MRI の情報が有用である，緊急性との兼ね合 いで選択する．深部感覚障害の評価には，通常の 診察以外に, 上記のように神経伝導検査, 体性感 覚誘発電位などの神経生理学的評価が有用で, 障 害部位の特定が可能となる. 脳血流シンチグラ フィーは神経変性疾患の初期などに有用である. 脊髄小脳変性症の初期では MRI にて小脳萎縮が 明らかでなくても, 小脳の血流低下が明らかなこと がある．亜急性に進行する小脸失調では傍腫瘍症 候群（抗 Yo 抗体など）を考慮する必要があり, 悪 性疾患の検索を実施する。保険適応外ではある が，検索法の 1 つとして PET は有用である.

\section{むすび}

上記に各責任病変別における運動失調について
述べた. 丁寧な問診により, ある程度病因の推測 が可能となり, 神経診察により責任病巣の特定が 多くの場合可能となる. 早期の診断確定により適 切な検査およびリハビリテーションを含む治療が 可能となる. 本総説が, 日常診療において, 病変 部位の特定・早期に診断確定に結びつけることの 一助となれば幸いである。

\section{文献}

1) Mochizuki H, Ugawa $Y$ : Disappearance of essential tremor after stroke : which fiber of cerebellar loops is involved in posterior limb of the internal capsule? Mov Disord $2011 ; 26: 1577$

2) Ugawa Y, Uesaka Y, Terao Y, Hanajima R, Kanazawa I : Magnetic stimulation over the cerebellum in humans. Ann Neurol $1995 ; 37$ : 703-713

3) Ugawa Y, Genba-Shimizu K, Rothwell JC, Iwata M, Kanazawa I : Suppression of motor cortical excitability by electrical stimulation over the cerebellum in ataxia. Ann Neurol $1994 ; \mathbf{3 6}:$ 90-96

4) Ugawa Y, Genba-Shimizu K, Kanazawa I : Suppression of motor cortical excitability by electrical stimulation over the cerebellum in Fisher's syndrome. J Neurol Neurosurg Psychiatry 1994; 57 : 1275-1276

5) Kikuchi S, Mochizuki H, Moriya A, NakataniEnomoto S, Nakamura K, Hanajima R, Ugawa Y : Ataxic hemiparesis : neurophysiological analysis by cerebellar transcranial magnetic stimulation. Cerebellum $2012 ; 11: 259-263$

6) Mochizuki H, Kamakura K, Kanzaki M, Nishii T, Matsuo H, Motoyoshi K : Somatosensory evoked potential in neurosyphilis. J Neurol $2002 ; 249$ : 1220-1222

7) Paquet N, Taillon-Hobson A, Lajoie Y : Fukuda and Babinski-Weil tests : within-subject variability and test-retest reliability in nondisabled adults. J Rehabil Dev 2014 ; 51 : 1013-1022 